Natural Hazards and Earth System Sciences (2003) 3: 569-580

(C) European Geosciences Union 2003

\title{
Observation of surface features on an active landslide, and implications for understanding its history of movement
}

\author{
Mario Parise \\ CNR-IRPI, c/o Istituto di Geologia Applicata e Geotecnica, Politecnico di Bari, Via Orabona 4, 70125 Bari, Italy
}

\begin{abstract}
Surface features are produced as a result of internal deformation of active landslides, and are continuously created and destroyed by the movement. Observation of their presence and distribution, and surveying of their evolution may provide insights for the zonation of the mass movement in sectors characterized by different behaviour. The present study analyses and describes some example of surface features observed on an active mass movement, the Slumgullion earthflow, in the San Juan Mountains of southwestern Colorado. The Slumgullion earthflow is one of the most famous and spectacular landslides in the world; it consists of a younger, active part which moves on and over an older, much larger, inactive part. Total length of the earthflow is $6.8 \mathrm{~km}$, with an estimated volume of $170 \times 10^{6} \mathrm{~m}^{3}$. Its nearly constant rate of movement (ranging from about $2 \mathrm{~m}$ per year at the head, to a maximum of 6-7 $\mathrm{m}$ per year at its narrow and central part, to values between 1.3 and $2 \mathrm{~m}$ per year at the active toe), and the geological properties of moving material, are well suited for the observation of the development and evolution of surface features.
\end{abstract}

In the last 11 years, repeated surveying at the Slumgullion site has been performed through recognition of surface features, measurements of their main characteristics, and detailed mapping. In this study, two sectors of the Slumgullion earthflow are analysed through comparison of the features observed in this time span, and evaluation of the changes occurred: they are the active toe and an area located at the left flank of the landslide. Choice of the sectors was dictated in the first case, by particular activity of movement and the nearby presence of elements at risk (highway located only $250 \mathrm{~m}$ downhill from the toe); and in the second case, by the presence of many surface features, mostly consisting of several generations of flank ridges.

The active toe of the landslide is characterized by continuous movement which determines frequent variations in the presence and distribution of surface features, as evidenced by the multi-year observations there performed. In addi-

Correspondence to: M. Parise (cerimp06@area.ba.cnr.it) tion, monitoring of the inactive material just ahead of the active toe showed that this sector is experiencing deformation caused by the advancing toe. Mapping and interpretation of the different generations of flank ridges at the narrowest and central part of the active Slumgullion landslide evidenced, on the other hand, the gradual narrowing of the mass movement, which was accompanied by a reduction in the thickness of the material involved in landsliding.

Multi-time observation of the surface features at the Slumgullion earthflow allowed to reconstruct the evolution of specific sectors of the mass movement. This low-cost approach, whose only requirements are the availability of a detailed topographic map, and repeated surveying, is therefore particularly useful to better understand the kinematics of active mass movements, also in order to design the more appropriate stabilization works.

\section{Introduction}

Identification of elements that characterize different parts of a landslide is an important aspect in the geomorphological analysis of mass movements. Features at the surface of active landslides are generally short-lived and can be quickly destroyed. However, depending on factors such as the type of landslide, the rate of movement, and the rheology of materials involved, in some cases they can persist, and their observation (especially when performed through periodic observations, in order to monitor their temporal evolution) might result in useful information for understanding the kinematics of the landslide and evaluating the related hazard (TerStepanian, 1967; Zaruba and Mencl, 1982; Varnes, 1984), as well as for recognition of different phases in its history of movement. In addition, observations at the surface have also provided useful insights for reconstruction of the geometry of slip surfaces (Hutchinson, 1983; Carter and Bentley, 1985; Cruden, 1986).

In this paper, the importance of the recognition and mapping of surface features on active landslides will be out- 


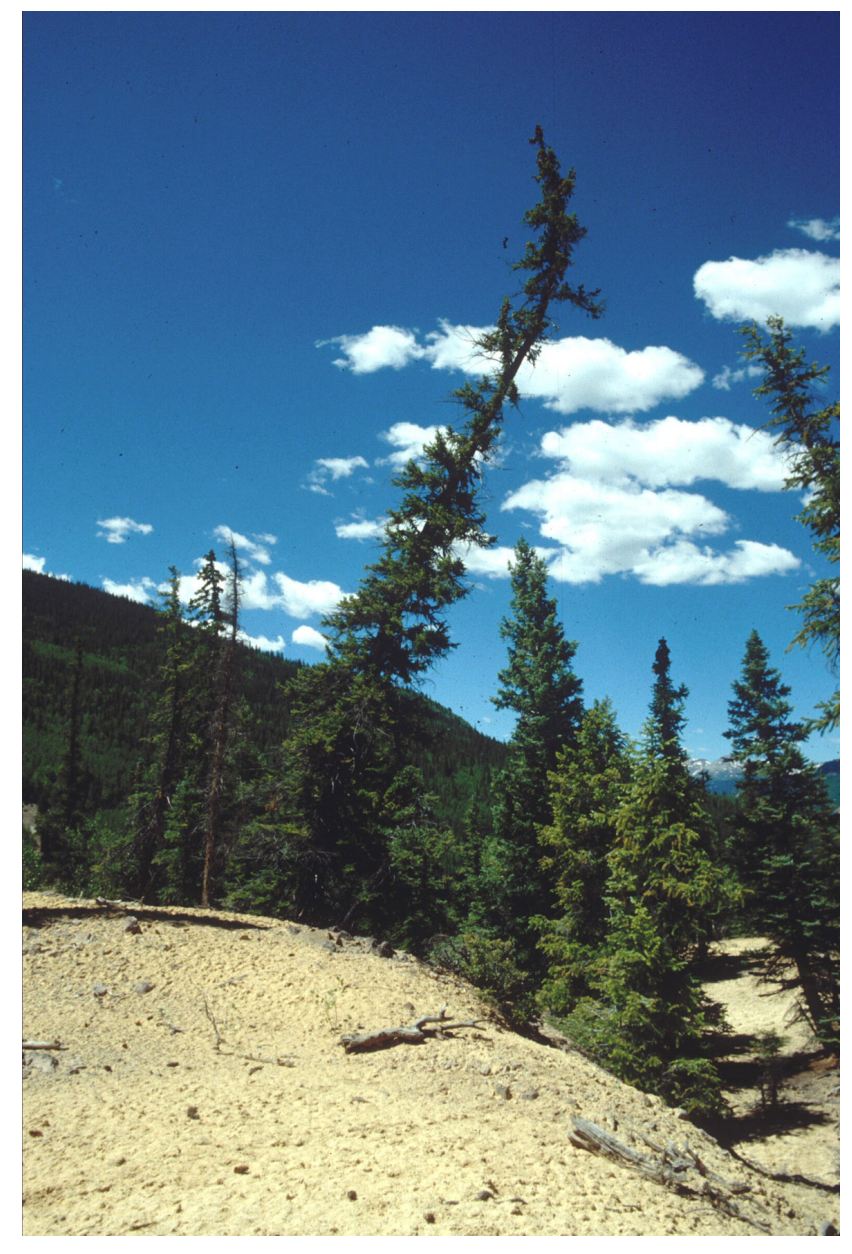

Fig. 1. Example of tilted tree, showing vertical growing after that displacement at the site caused the curvature in the trunk.

lined by describing multi-time surveying performed over a 11 year time span at the Slumgullion landslide, one of the best-known mass movements in the world.

\section{Surface features of active landslides}

Active landslides (sensu WP/WLI, 1993) are generally characterized by deformational features that are the result of differential movement within the mobile mass and between this mass and the underlying material. The nature of the features, as well as their positions and orientations, are indicative of different kinds of deformation. Their large-scale mapping, together with information derived from indirect indicators, may help in understanding the behavior of different parts of the landslide, and can eventually allow a zonation into landslide elements.

Many different types of features can be observed at the surface of active landslides, including scarps; fractures; basins; areas of temporary or permanent water ponding; ridges, etc. Each of these features is related to the style of deformation acting at that moment, or which has been active in past times, in that particular part of the landslide. Many of them are ephemeral, since weathering, erosion and ongoing deformation tend to erase prior traces of movements (Wieczorek, 1984).

It is possible to discriminate between direct and indirect indicators of deformation (Fleming et al., 1999): the first are those structures directly connected to structural discontinuities affecting the landslide material (IAEG Commission on Landslides, 1990), while the latter lack this direct association. Nevertheless, indirect indicators may provide information about the type and style of local deformation. Indirect indicators include, for example, changes in the hydrography at the surface of the landslide and changes to the vegetation cover. Active landslides, and sometimes even dormant ones, typically have very high moisture contents. Ephemeral and perennial streams occur or are located, respectively, within the landslide and along its flanks. Changes in location and discharge of springs, and diversions in the pattern of the drainage network can be used to derive information about changes in the type and style of deformation (Williams, 1988).

Further information can be obtained through the observation of trees and vegetation, since these are often affected by phases of movement and may register different episodes of displacement. The distribution of vegetation cover on the landslide, and the degree of vegetation disturbance, can be used to indicate the amounts of movement occurring across the landslide and even the relative ages of these movements. Continuously active areas are generally characterized by bare ground, or at least by the presence of relatively few trees, whilst in areas of recent movement the trees show clear signs of disturbance. Often trees are tilted during the movement, and then grow vertically during the period of inactivity, leaving a characteristic "stem bend" (Fig. 1). The relative age of the movement can then be inferred by these curvatures in the tree trunks.

In several areas, the observation of trees may also allow the determination of the width of tension cracks and the amount of lateral movement along shear surfaces. This is the case for trees split into two or more parts because they straddle active cracks (Fig. 2). The direction of differential movement required to produce the split can be used, together with stretching or buckling of tree roots, as an indicator of local deformation (Fleming et al., 1999). Often the trees are still alive in spite of the breaking.

The present study, by illustrating large-scale geomorphological mapping of surface features on an active landslide, and their interpretation through multi-time observations, is intended to stress the use of these information for a better understanding of the landslide kinematics, and the possibility to perform a zonation into landslide elements that are characterized by different styles of deformation. The methodology here illustrated for the Slumgullion landslide may be easily exported to other slow-moving mass movements, where large scale topographic maps are available. 

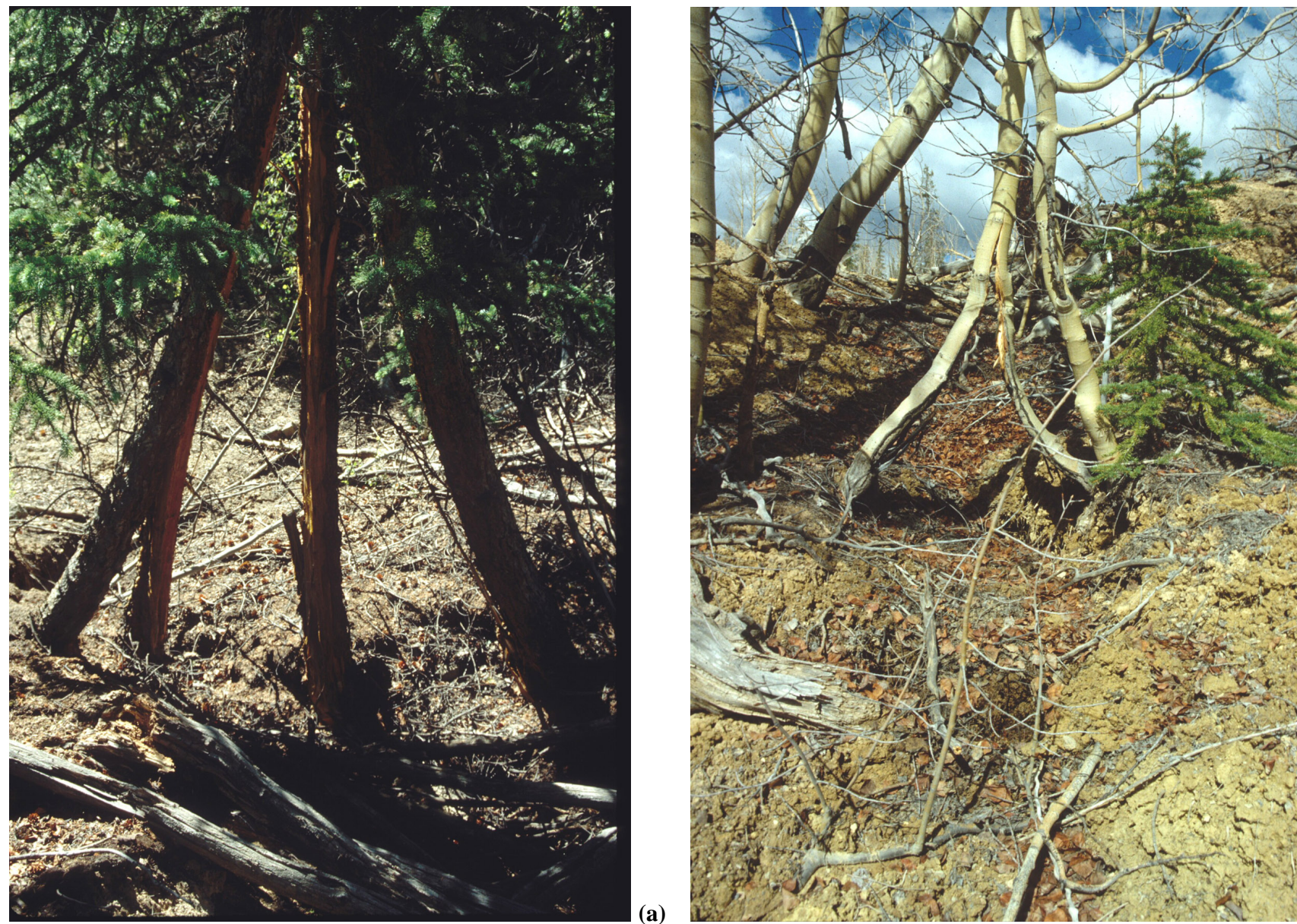

(b)

Fig. 2. Trees split in, respectively, four and two parts because they straddle active cracks: (a) spruce fir; (b) aspen tree. Both the trees were still alive at the time the pictures were taken.

\section{General setting of the Slumgullion landslide}

The site of this study is the world famous Slumgullion landslide $^{1}$, a large mass movement in the San Juan Mountains of Colorado (Fig. 3). It consists of a younger, active movement (3.9 km long) with an estimated volume of about $20 \times 10^{6} \mathrm{~m}^{3}$ (Parise and Guzzi, 1992), which moves on and over an older, much larger (6.8 km long), inactive landslide (Fig. 4). Overall, the volume of the complete landslide system is estimated at about $170 \times 10^{6} \mathrm{~m}^{3}$ (Parise and Guzzi, 1992).

\footnotetext{
${ }^{1}$ Observations dealing with the kinematics of the movement at Slumgullion site have shown that most of the movement of the active part of the Slumgullion earthflow takes place along the shear surfaces that also define the flanks of the landslide (Crandell and Varnes, 1960, 1961; Guzzi and Parise, 1992; Baum and Fleming, 1996; Fleming et al., 1999). Therefore, it is more correct to refer to it as an earth slide or landslide (IAEG Commission on Landslides, 1990; Cruden and Varnes, 1996). However, since it has been described for a long time as earthflow (and sometimes also used as typical example for this category of slope movement), the term earthflow has become and still remains traditionally popular for the Slumgullion. In this paper, I use interchangeably the terms earthflow and landslide in referring to the slope movement.
}

The Slumgullion landslide formed as a result of the collapse of hydrothermally altered volcanic materials in the rim of the Lake City caldera (Lipman, 1976), on the south end of the Mesa Seco plateau. The landslide deposit flowed downhill, deviating the original course of the Slumgullion Creek, and eventually damming the Lake Fork of the Gunnison River, creating Lake San Cristobal (Schuster, 1985). The materials exposed in the scarp are hydrothermally altered and unaltered volcanic rocks including tuffs and intrusive and extrusive rocks of variable compositions (Diehl and Schuster, 1996). The hydrothermal brecciation and alteration, combined with the weakening of the rock mass by intersections of numerous faults, was apparently a prime factor in the origin of the Slumgullion landslide. In fact, most of the material observed on the landslide consists of silts and clays with low strength, medium to high plasticity and high swelling potential (Chleborad et al., 1996). Locally, large assemblages of boulders are present.

This occurs in particular at the base of the main scarp, which is mantled with continuous belt of detrital material consisting of talus cones and rock-fall deposits (Fig. 5). The talus cones are built by successive and discontinuous accumulations of debris falling from the near-vertical to over- 


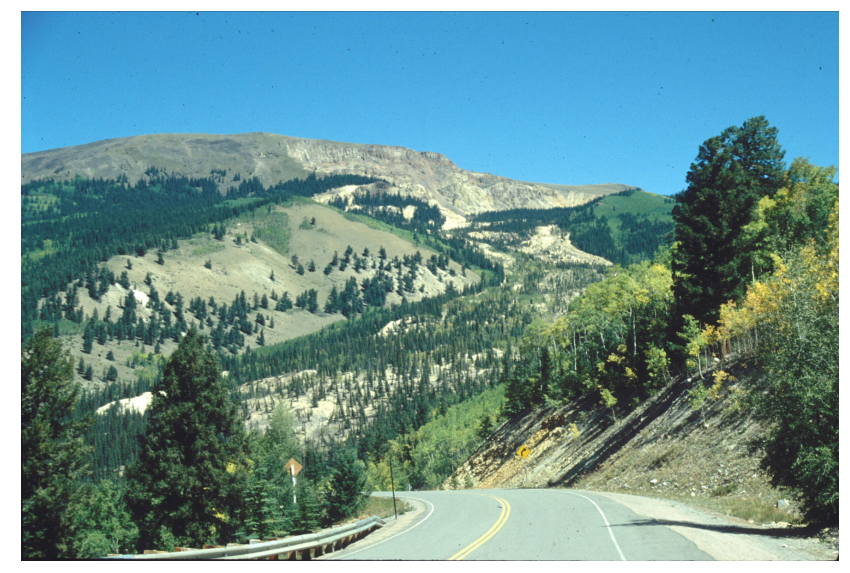

Fig. 3. View of the Slumgullion landslide, taken uphill from the State Highway 149.

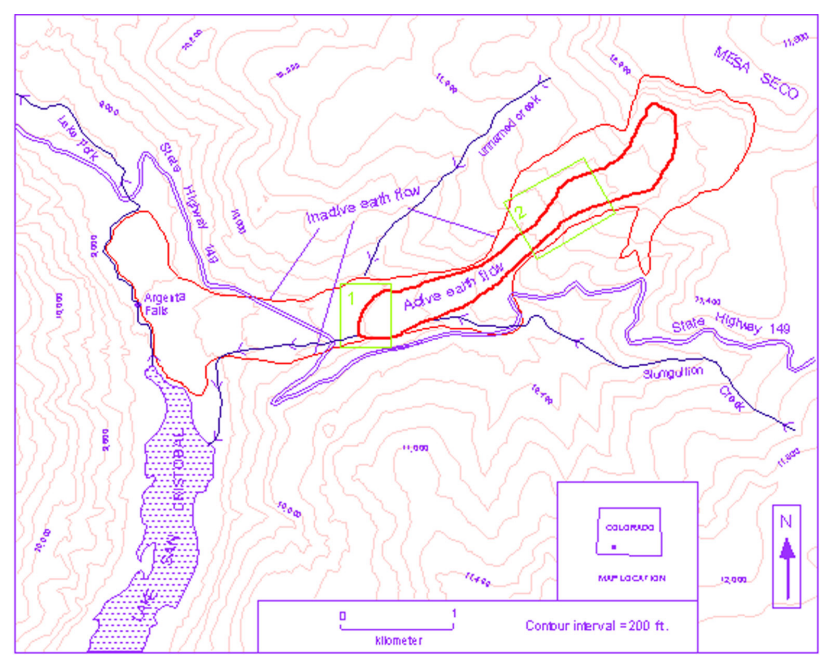

Fig. 4. Location map showing the boundaries of both inactive and active parts of the Slumgullion earthflow. The two sectors described in the paper are shown as insets: (1) the active toe; (2) the narrowest part of the active landslide.

hanging rock walls above. Rock-fall deposits, on the other hand, form large accumulations of clast-supported angular blocks and coarse boulders, which typically show an irregular hummocky morphology (Parise and Moscariello, 1997).

The Slumgullion earthflow has attracted the attention of investigators since the 19th century when Endlich (1876) described it in a short note in the report of the Hayden Survey of 1874. It has since been cited by numerous other investigators (Cross, 1909; Howe, 1909; Atwood and Mather, 1932; Burbank, 1947, for example). The earliest photographs of the landslide were published at the beginning of the 20th century by Whitman Cross (plate XXB in Howe, 1909). However, even though it has been known about for a long time, and indeed it has become one of the most famous mass movements in North America, the only specific study of the Slumgullion landslide was undertaken by Crandell and Varnes, who in 1958 measured the movement of the landslide (Crandell

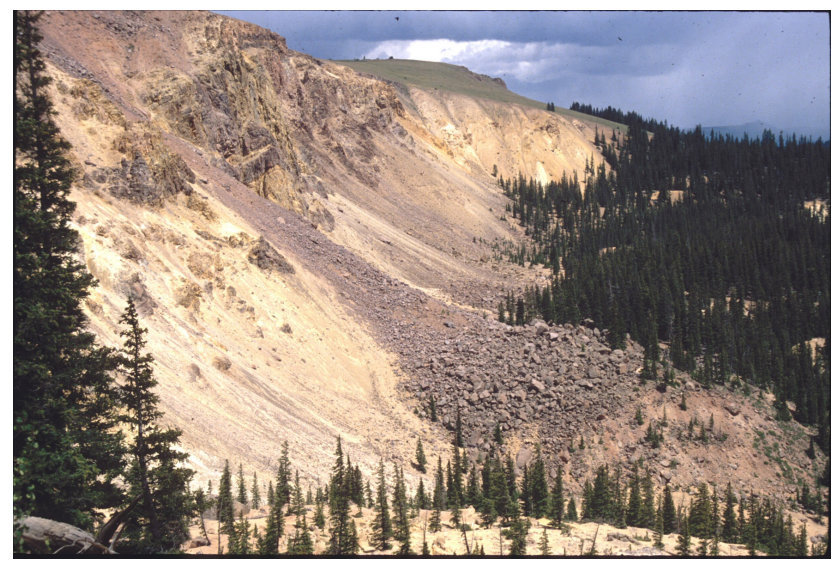

Fig. 5. Talus deposits at the base of the Slumgullion main scarp.

and Varnes, 1960, 1961). Observations of changes in the survey lines crossing the slide, and of advances of the active toe, were made several times between 1958 and 1973. Eventually, in 1990 the United States Geological Survey (USGS), in cooperation with the National Research Council of Italy (CNR), initiated a program devoted to studying and monitoring the landslide.

Some characteristics of the Slumgullion landslide are particularly favourable for the observation and analysis of surface features; they essentially are: (1) the overall slow velocity; (2) the nearly constant rate of movement; (3) the geological properties of moving material; (4) the low levels of anthropogenic modification.

Monitoring of the landslide, which has been discontinuously performed since 1958 , has showed that the velocity ranges from about $2 \mathrm{~m}$ per year at the head, to a maximum of 6-7 $\mathrm{m}$ per year at its narrow-central part, to values between 1.3 and $2 \mathrm{~m}$ per year at the active toe (Fig. 6).

Since 1998, GPS (Global Positioning System) observations have been performed on the active portion of the Slumgullion landslide, and the seasonal movement has been interpreted in the context of selected hydrologic and meteorologic data (Coe et al., 2000, 2003). The main output of this study is that the landslide moves throughout the year, but daily velocities are highly variable on a seasonal basis. Seasonal variability in velocities is probably due to changes in ground-water levels, which decrease when surface water is unavailable or cannot infiltrate frozen ground and increase when surface water from melting snow or rainfall infiltrates unfrozen ground. This hypothesis is supported by data showing seasonal changes in soil-water content and by a correspondence between the velocity and air- and soil-temperature data from a meteorological station on the slide (Coe et al., 2003). In general, the velocity of the slide increases or decreases with rising or falling temperatures. Annual movements and daily velocities are lowest at the head and toe of the landslide and highest in the central, narrowest part of the landslide. Movements and velocities deviated from this distribution in areas where they were affected by major struc- 


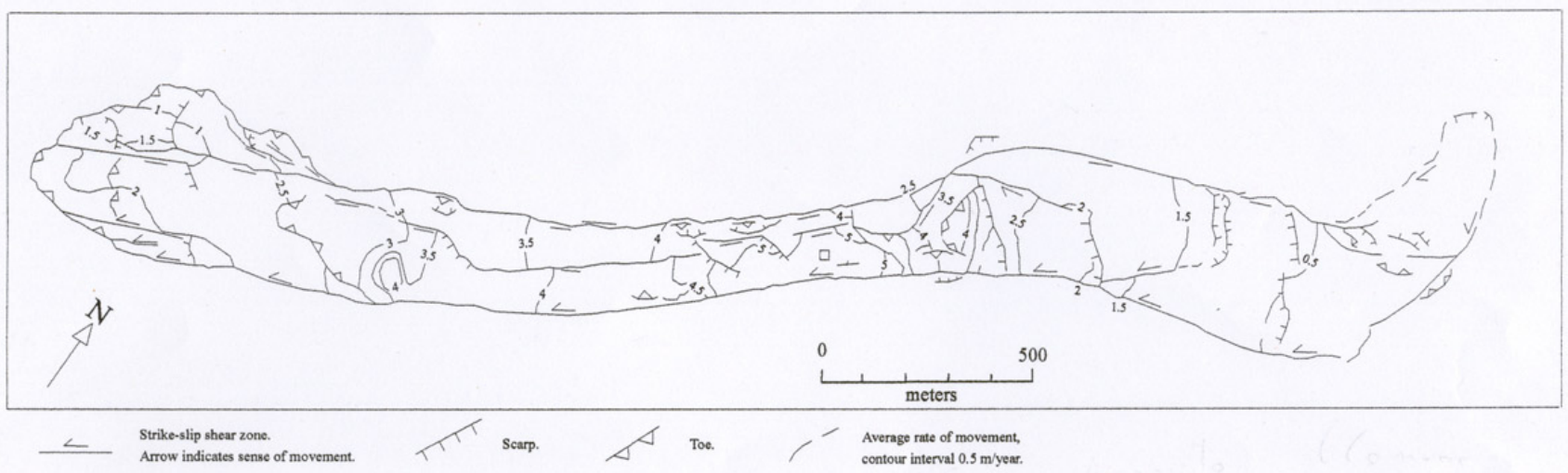

Fig. 6. Sketch of the Slumgullion landslide, showing average velocities as obtained from field measurements and photogrammetric analyses (data from Smith, 1993, and from Fleming et al., 1999). The square at the narrowest part of the landslide indicates the approximate site of maximum velocity, reaching about $7 \mathrm{~m} /$ year.

tural elements within the slide (Gomberg et al., 1995; Baum and Fleming, 1996).

\section{Observation of surface features at the Slumgullion landslide}

In the active part of the Slumgullion landslide, two sectors have been chosen for detailed analysis of the surface features, and for evaluation of their evolution: they are the active toe, and the flanks of the landslide at its narrowest part (Fig. 4). Choice of the sectors was dictated in the first case by particular activity of movement and the nearby presence of elements at risk; in the second case, by the presence of the most prominent surface features of the landslide, the flank ridges.

\subsection{The active toe}

The first sector described is the distal portion of the active landslide, and in particular the active toe (Fig. 4). This is an area of particular interest, due to the nearby presence of a communication route: State Highway 149 runs only $250 \mathrm{~m}$ downhill from the active toe and is at risk from a continuation of the current landslide movement pattern. To determine if loading exerted by the currently moving material causes deformation of the inactive deposits, a team led by David J. Varnes (USGS) began surveying this part of the landslide in 1991. The surveys undertaken to date indicate that the inactive part of the Slumgullion earthflow is responding to the load caused by the advancing toe, and is not as stable as previously assumed (Varnes et al., 1996).

In this area, based on the results of seismic reflection and refraction profiles, Williams and Pratt (1996) estimated a maximum landslide thickness of about 95 along a profile below the active toe and to the east of State Highway 149 (Fig. 4). At the same site, on the other hand, Parise and Guzzi (1992) suggested, based upon geomorphic considerations, a thickness of about $120 \mathrm{~m}$.

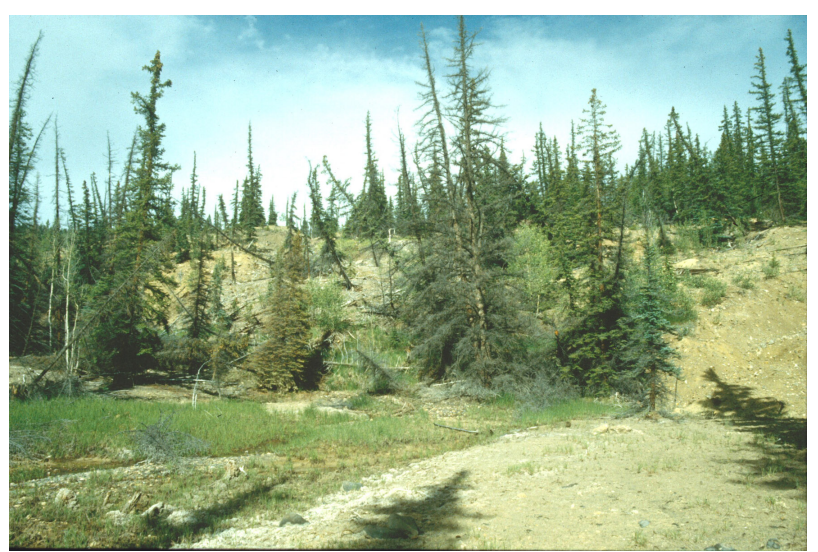

Fig. 7. Active toe of the Slumgullion earthflow, about $250 \mathrm{~m}$ upslope from the area where State Highway 149 crosses the inactive landslide deposit.

In plan view the active toe is rounded, whilst in profile it has a steep frontal slope, from 30 to $40 \mathrm{~m}$ high, with an average slope angle of $18^{\circ}$. The overall difference in elevation between the active and inactive deposits is accommodated through a series of scarps, whose height ranges from 0.5 to $8 \mathrm{~m}$. Behind the toe, the slope angle decreases to an average value of $8^{\circ}$.

The active toe is moving along the surface of the old landslide deposits in bulldozer fashion, toppling and overriding trees as it goes (Fig. 7). It has an irregular trace along its northern half, which is probably a result of a velocity discontinuity (higher displacement rates have actually been observed at its southern half).

The principal feature of the active toe is a series of scarps, ranging in height from 0.5 to $8 \mathrm{~m}$. Most of them are the main scarps for minor landslides, primarily slumps. Pressure ridges are present on the northern and northwestern sides of the toe, with several steps whose height ranges from 0.3 to $1.2 \mathrm{~m}$. 


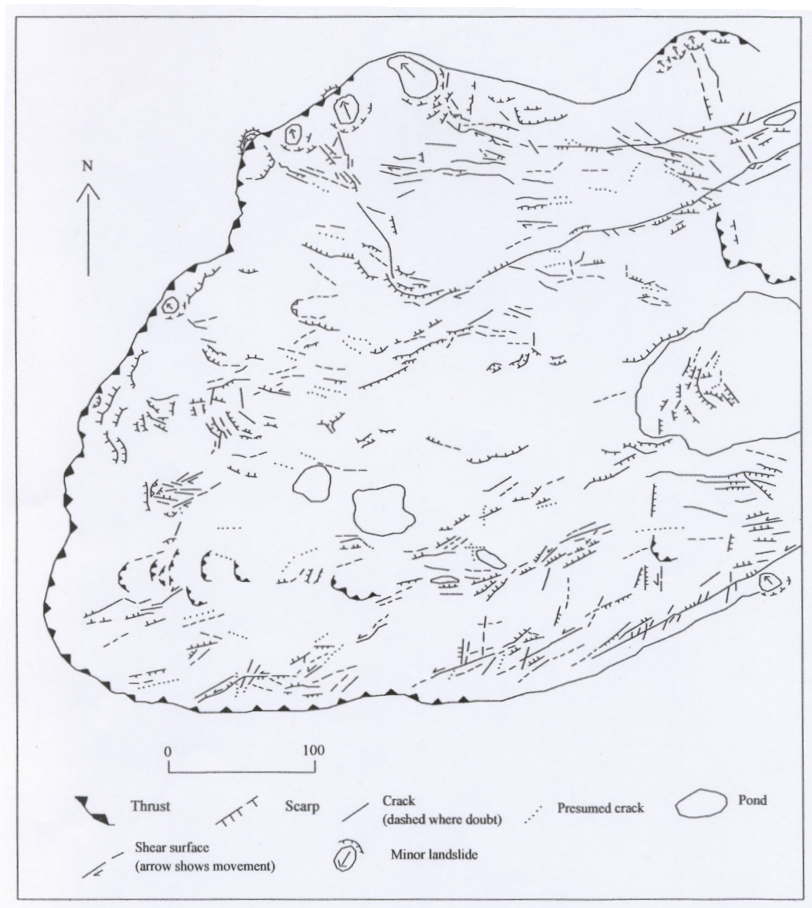

Fig. 8. Map of surface features at the active toe of the Slumgullion landslide, as mapped in June-August 1991 (simplified after Guzzi and Parise, 1992).

Since the first surveys carried out at the Slumgullion site, it appeared that the active toe was one of the most rapidly evolving places in the landslide. Superimposition of minor mass movements, and the push exerted by the material advancing from behind, produce significant deformations and changes in the morphology of this sector. Development and evolution of surface features produced by landslide movement at the active toe can be appreciated by comparing the maps by Guzzi and Parise in 1991 (Fig. 8) and by Fleming and others in 1993 (Fig. 9): both maps were produced by using as topographic base a 1:10000 scale map derived from the 1990 aerial photographs. Some features deserve to be here described briefly: in the 1991 surveying and mapping, pressure ridges were mapped at the northern and northwestern margins of the toe. Produced by deformation of stable ground in front of the active toe, they showed several steps with height ranging from 0.3 to $1.2 \mathrm{~m}$. The 1993 map (Fig. 9) also shows the presence of pressure ridges, even though most of these structures had already been partially destroyed by the bulldozing effect of advancing material. More recent surveys (up to the most recent one in August 2001) showed that no pressure ridges are now visible in that area, since they have been completely overridden by the movement.

The most important aspect deriving from the comparison of the 1991 and 1993 maps is probably the better development at the ground of the shear surface that separates the toe into two sectors characterized by different velocities and styles of deformation: a few hundred meters uphill from the active toe, there is an increase in the width of the active land-

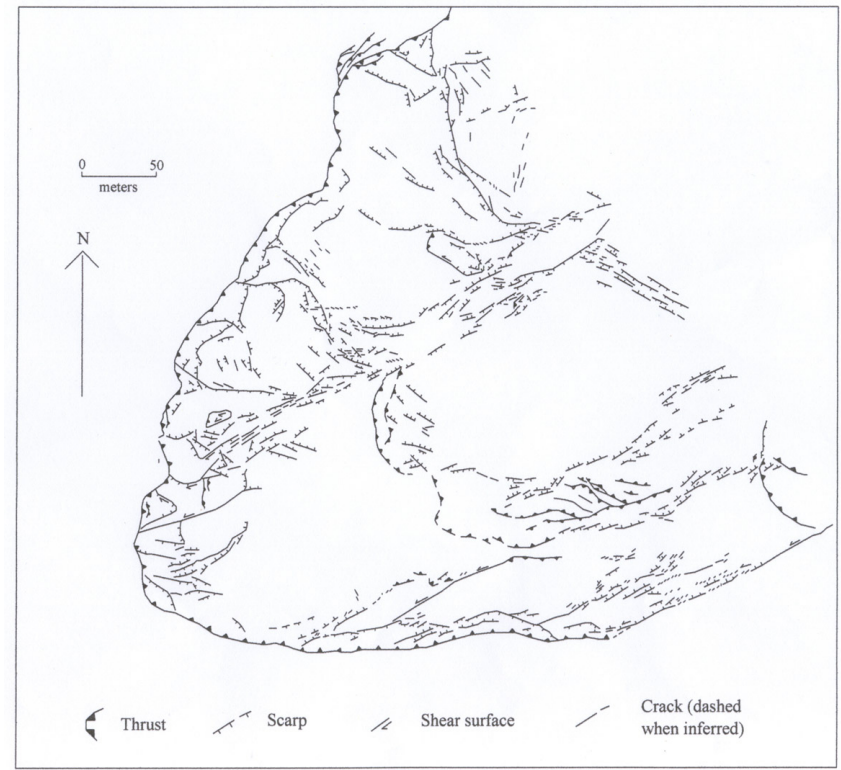

Fig. 9. Map of surface features at the active toe of the Slumgullion landslide, as mapped in 1992-93 (simplified after Fleming et al., 1999).

slide, which is a result of spreading along the north flank. This zone of spreading contrasts with a zone of shortening on the south side, and the two zones are separated by a major shear surface. This shear surface is recognizable in the 1991 map from the area north of the larger of the two ponds (Fig. 8); moving downhill, after about $200 \mathrm{~m}$, there is no clear evidence of the shearing at the ground surface, but a series of scarps and cracks can be identified, even though there is no clear throughgoing surface. In the 1993 map (Fig. 9) the scarps are much more continuous and connected, testifying the development at the surface of the structural discontinuity. The zone of spreading, located north of the shear surface, presents a lower velocity, in the range $0.3-1.4 \mathrm{~m} / \mathrm{year}$; on the other hand, the southern sector of the toe, where most of the movement appears to be now concentrated, shows a velocity between 1.3 and $2.5 \mathrm{~m} /$ year. The higher deformation and displacement of this sector is also shown by internal toes, located 100-150 $\mathrm{m}$ from the boundary of the active toe, at the downslope margin of the ponds that were identified in 1991. Therefore, the major shear surface which separates the two sectors of the toe appears much more pronunciated in 1993 than in 1991; the more recent surveys have furthermore confirmed its longest morphological expression at the ground surface. The multi-time surveying showed in this case how an important feature became more visible at the surface of the landslide with time; the difference in velocities north and south of this shear surface again confirms the prominent role it is playing in the landslide evolution. However, it is worth noting that its presence had already been recognized and mapped during the first surveys in 1990.

In the last few years, further changes have occurred at the active toe, in the form of debris flows that affected its central 

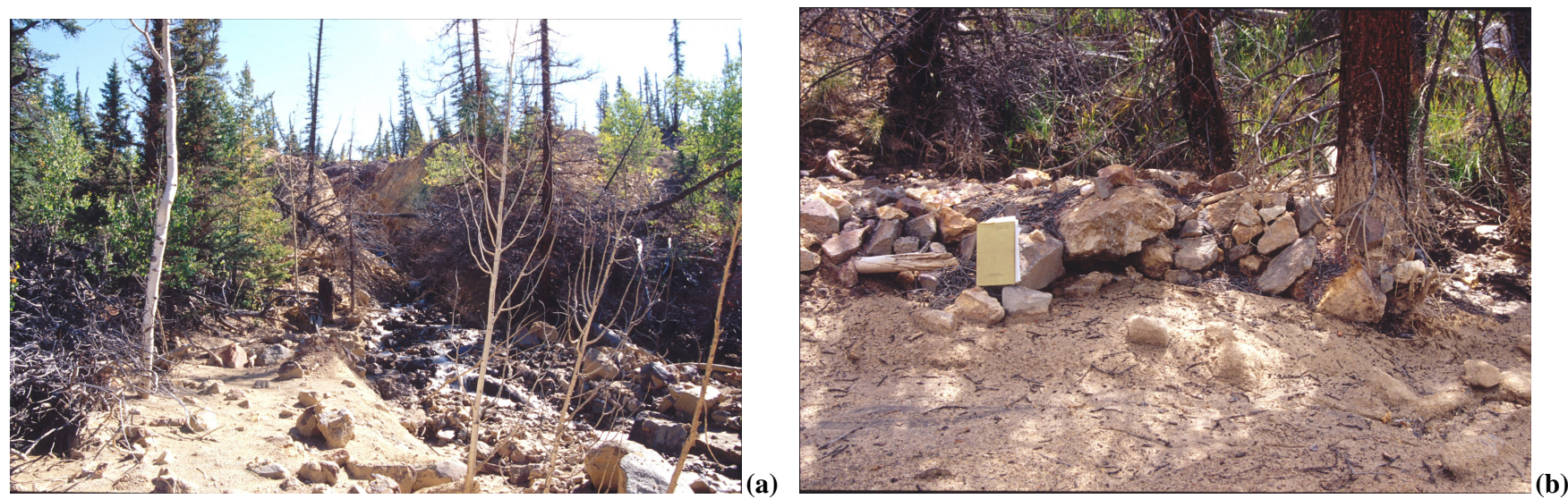

Fig. 10. Path (a) and deposits (b) from debris flows occurring at the active toe.

part. Starting from the steep sectors at the upper part of the toe, the debris material moved following one of the main water lines (Fig. 10a), and invaded the area just downhill from the active toe. The sector affected by these processes is located about along the direction of the major shear surface described above. Debris flows occurred in 1999 and 2000, even though the exact dates of occurrence are not available (W.Z. Savage, personal communication). Debris-flow deposits consist of sub-rounded to sub-angular boulders, cobbles and pebbles in a fine matrix. A train of boulders and splash marks on tree trunks up to a height of $50 \mathrm{~cm}$ have been observed (Fig. 10b). Several small flank ridges, $0.4 \mathrm{~m}$ high, are also present, showing sub-angular clasts aligned at their top. Spreading of the debris material was so extensive that some of the control points of Varnes' network were destroyed by the debris or covered to a thickness of some 10 to $20 \mathrm{~cm}$.

Observations of the displacement vector of the active toe relative to nonmoving ground indicate continuing thickening of the toe (Fleming et al., 1999); therefore, displacement of the landslide tends to steepen the front of the active toe. This could still increase deformations in the area ahead of the active toe, as well as favouring minor mass movements at the steep and unstable active front.

\subsection{The flank ridges at the narrowest part of the landslide}

The second study area is located at the narrowest part of the landslide (Fig. 4). Narrowing of the landslide is accommodated in an area where the width decreases from the about $300 \mathrm{~m}$ to $230 \mathrm{~m}$ and then to $150 \mathrm{~m}$, where Crandell and Varnes $(1960,1961)$ measured the maximum displacement rate and established a survey line (Fig. 6). The narrowing is also accompanied by an abrupt change in slope. This sector is characterized by flank ridges that are commonly the best preserved feature of active landslides, especially of the flow type. They have been studied by many authors (e.g. Rickmers, 1913; Sharp, 1942; Johnson, 1970), described with many different names (including levees, rims, lateral ridges, etc.), and interpreted in different ways. Keefer and John- son (1983) distinguished three different ways ridges can form at the flanks of an earthflow; Zaruba and Mencl (1982) and Fleming et al. (1988) used the height of the flank ridges to estimate the displacement of landslides. Fleming and Johnson (1989) distinguished ridges formed by deposition from those formed by deformation of landslide debris; they also surveyed the growth of flank ridges and the development of structures associated with them. Corominas (1995) has more recently reviewed many of the proposed mechanisms for formation of flank ridges; he made a strong case for basal erosion and shear in the development of flank ridges.

On the active part of the Slumgullion landslide, several generations of ridges are present, both on the flanks of the landslide and within it (Fig. 11). Some of them are actively growing, as indicated by the freshness of the exposed debris and the development of small lateral landslides.

In plan view, the flank ridges are elongate, convex downward at their termini, and generally symmetric. The axes of the flank ridges mostly follow the curvature of the boundaries of the landslide. Their course can be continuous for long distances, up to hundreds of meters, or it can be discontinuous so that the ridge is formed by several segments. Width is always very small with respect to length. The height of the ridges ranges from tens of centimeters to $30 \mathrm{~m}$.

The flank ridges are generally bounded by a more or less continuous shear surface, which is recognizable at the ground, or whose presence can be inferred by the en echelon cracks, which generally represent the precursory feature of a shear surface proceeding toward the ground (Pollard et al., 1982; Deng et al., 1986). Even though related to the gravitydriven movement of the landslide, these shear surfaces have also been described as strike-slip faults (Baum and Fleming, 1991; Baum et al., 1993; Gomberg et al., 1995), due to their analogy with these structural discontinuities (Segall and Pollard, 1980; Sylvester, 1988).

The flank ridges are commonly characterized by the concentration of the coarser and rocky material in their upper part, forming the typical armoring that probably indicates upward transport (Fig. 12). Where very narrow ridges are 

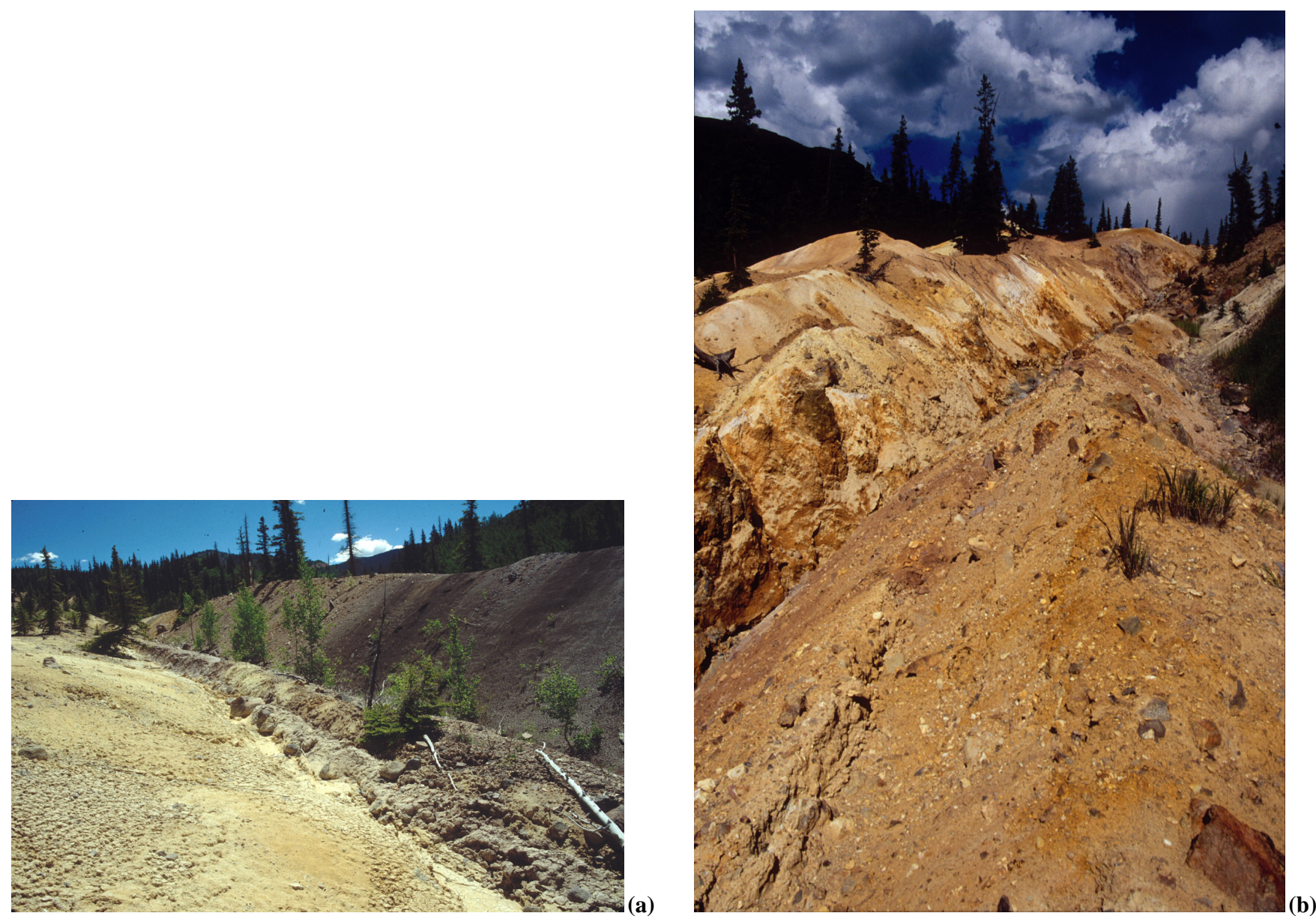

Fig. 11. Flank ridges: (a) at the left boundary of the Slumgullion landslide; note the difference in height between the presently forming flank ridge and the older one. (b) within the landslide body.

formed, the coarser material is also present on the side of the ridges. The boulders are often arranged with their longest axis perpendicular to the direction of the ridge. On the basis of observations of the main flank ridges at the Slumgullion landslide, it has been hypothesized that these boulders can be interpreted as the remnants of a wider cover made up by large blocks that was reworked and dismembered by the building up of the flank ridges (Parise et al., 1997). They should thus derive from boulder fields related to ancient rock-fall events. Within the body of the landslide, active ridges also form near minor shear surfaces. They have in general the same characteristics as those along the flanks but are commonly smaller. Moreover, they appear to be more disturbed because of other differential movements within the landslide. As a result, there are scarps and tension cracks subparallel to the axis of these ridges combined with other features that apparently are not directly connected to their development and growth.

In transverse profile, the flank ridges show a convexupward curve and V-shaped troughs on either side; the shape is then generally rounded if height and width are comparable. With increasing height, narrow ridges with steep slopes on both sides form. The ridges closer to the boundaries of the landslide are generally parallel to each other, and in turn to the shear surface. In some cases the orientations are slightly convergent, reflecting local variations in the direction of movement, and/or the development of minor shear surfaces not parallel to the main one.

There is a large contrast between the size of the older ridges and of those that are currently active (Fig. 11a): the inactive ridges are much larger, up to $30 \mathrm{~m}$ high. Those on the extreme outside of the landslide are the largest and, based on the size of trees and development of soil, appear to be the oldest.

Flank ridges that have formed along the flanks of a landslide provide a basis to evaluate the history of movement in much the same way as moraines are useful indicators of movement history of a glacier. Observation of the main geomorphic, pedologic, and sedimentologic features (Table 1) of the several generations of flank ridges at the Slumgullion landslide helped in reconstructing the chronology of their formation and to relate them to the so far reconstructed landslide history of movement (Madole, 1996; Parise et al., 1997; Fleming et al., 1999). This was obtained by surveying the variability of their features, including size of the ridges, the reciprocal relationships, continuity, main direction of the 
Table 1. Features used for the chronology of formation of the flank ridges at the narrowest part of the Slumgullion earthflow. Sets of flank ridges labeled as in Figs. 13 and 14, and as in the text

\begin{tabular}{|c|c|c|c|c|c|}
\hline Set of flank ridges & $\begin{array}{l}\text { Maximum } \\
\text { height (h) }\end{array}$ & $\begin{array}{l}\text { Maximum } \\
\text { width (w) }\end{array}$ & $\begin{array}{l}\text { Inner slope } \\
\text { gradient }\end{array}$ & Vegetation cover & $\begin{array}{l}\text { Munsell's soil color } \\
\text { (after Munsell, 1954) }\end{array}$ \\
\hline 1 & $10 \mathrm{~m}$ & $24 \mathrm{~m}$ & $30^{\circ}$ & fully vegetated & very pale brown [10YR 7/4] \\
\hline 2 & $14 \mathrm{~m}$ & $32 \mathrm{~m}$ & $36^{\circ}$ & fully vegetated & brownish yellow [10YR 6/6] \\
\hline 3 & $18 \mathrm{~m}$ & $48 \mathrm{~m}$ & $40^{\circ}$ & party vegetated & $\begin{array}{c}\text { yellow [10YR 7/6] with } \\
\text { pinkish gray patches [7.5YR 6/2] }\end{array}$ \\
\hline 4 & $8 \mathrm{~m}$ & $20 \mathrm{~m}$ & $35^{\circ}$ & $\begin{array}{l}\text { partly vegetated; } \\
\text { locally no vegetation }\end{array}$ & yellowish red [5YR 5/8] \\
\hline dashed ridge & $5 \mathrm{~m}$ & $33 \mathrm{~m}$ & $16^{\circ}$ & fully vegetated & $\begin{array}{c}\text { yellow [10YR 7/8] - } \\
\text { brownish yellow [10YR 6/8] }\end{array}$ \\
\hline
\end{tabular}

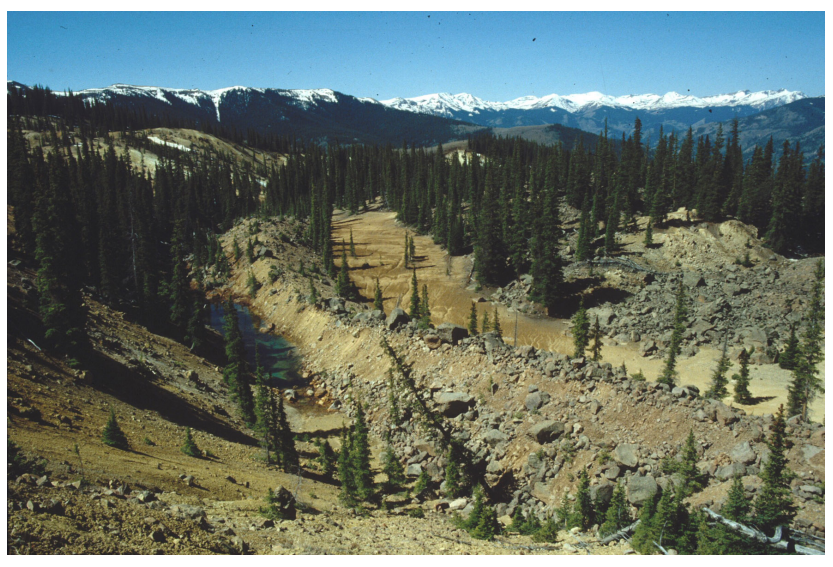

Fig. 12. Armoring at the top of the main flank ridge bounding the upper part of the active Slumgullion earthflow.

axes, presence and type of vegetative cover and of soils. Figure 13 is a sketch of the narrowest part of the active landslide, where a tentative chronology of the formation of flank ridges has been identified: the reconstruction of relative ages for ridges is numbered from 1 to 4 , with 1 being the oldest (Figs. 13 and 14). Number 1 refers to a phase probably related to movement of material from a secondary source area: it diverges from most of the other ridges, and is cut by flank ridge 2, whose main axis follows the direction of the active landslide. Flank ridge 3 is the closest to the present boundary of the active landslide; it shows good continuity and a fresher appearance than the two previous sets. Locally, there is a further set (number 4), with smaller values of its morphometric parameters.

Sets 2 and 3 of flank ridges were used, because of their continuity along most of the landslide, to estimate previous width and thickness of the landslide at the time of formation of the flank ridges: in fact, location and distribution of the different sets of flank ridges indicate past boundaries of the landslide, and there is a direct relationship between thickness of the material involved in the movement and size of the bounding flank ridge. This analysis showed that the decreasing width of the landslide occurred with a reduction in the thickness of material involved in the movement (Parise et al., 1997). Thus, after formation of the largest flank ridges that mark the outer boundaries of Slumgullion, other successive phases of movement, or perhaps continual movement of a gradually decreasing volume of material, led to the building of new ridges within the older and larger ridges.

Thinning and narrowing of the Slumgullion landslide is due to decreasing sediment supply from the source area, and might progress until the lower reaches of the landslide could no longer move. Similar thinning and narrowing, again documented by recent mapping (Fleming et al., 1999), will eventually result in inactivity of the presently active part of the landslide unless there is an increase of material available in the source area.

\section{Discussion and conclusions}

For all except the most simple forms of mass movement, displacement produces internal deformation in the landslide mass. Each part of a landslide is generally characterized by different types and orientations of structures. The rate and type of movement, material properties, and boundary conditions as well as initial and changing stresses interact to produce complex structures at the landslide ground surface. Areas with simple structures that are related to only a single type of deformation are rare on a large, complex mass movement such as Slumgullion.

Nearly constant movement makes this landslide an excellent, large-scale natural laboratory. Mapping and interpretation of the features produced by the movement along the active margins and within the body of its active part show that the Slumgullion landslide can be partitioned into separate regions based on the style of deformation. The main scarp and the head of the slide exhibit a prevailing extensional style of deformation, expressed under the forms of scarps perpendicular to the main direction of movement. Deformation in the narrow, central part of the landslide is characterized by the 


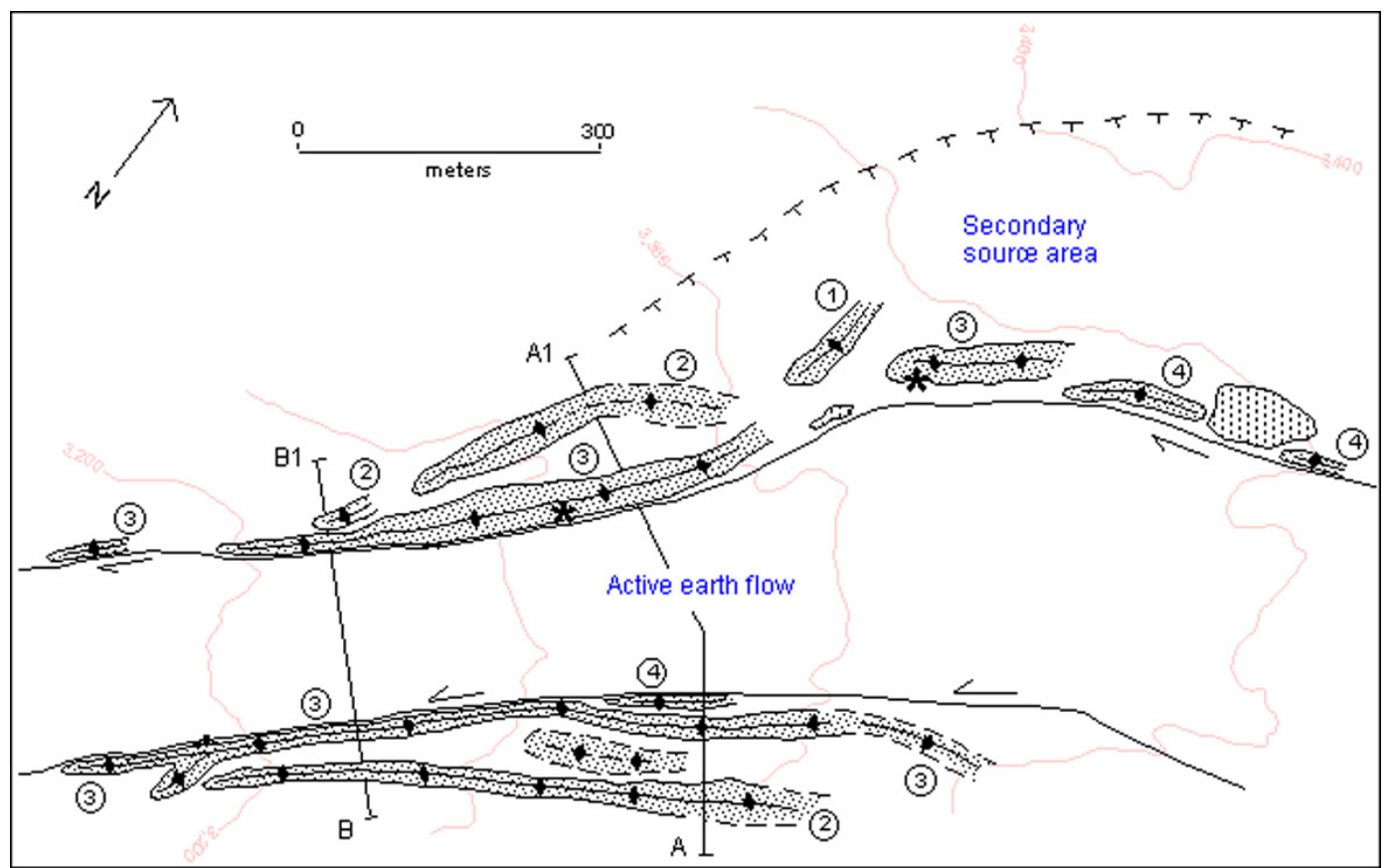

Fig. 13. Sketch of the narrowest part of the Slumgullion landslide, showing the several generations of flank ridges and their relative chronology (from the oldest 1 to the youngest 4). Traces of the transverse profiles of Fig. 14 are shown.

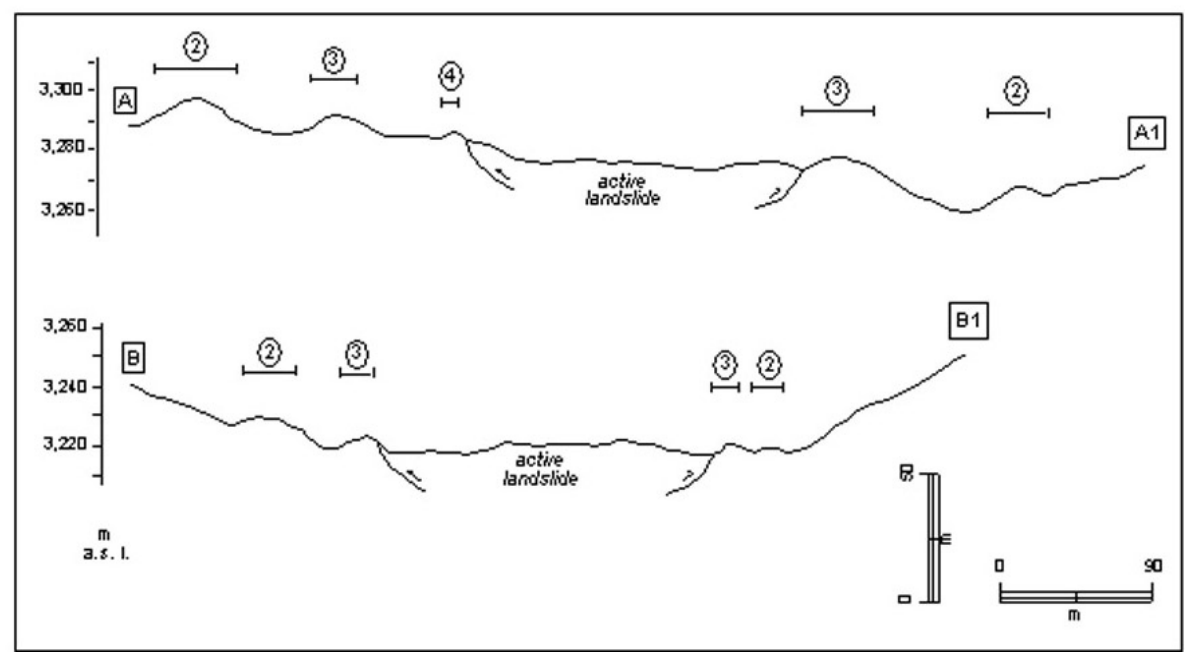

Fig. 14. Transverse profiles (looking downslope) at the narrowest part of the Slumgullion landslide. Location of profiles is shown in Fig. 13.

main shear surfaces bounding the active landslide, and their related features. The toe of the slide, eventually, is a region of compressive deformation, particularly well shown downhill from the main pond.

The pattern of the overall movement at the landslide surface is consistent with the above zonation; it shows in fact that the highest surface-flow velocity, averaging $6-7 \mathrm{~m} / \mathrm{yr}$, occurs halfway down the active portion where the earthflow is confined to a width of $150 \mathrm{~m}$. Flow velocities in the upper, wider part of the flow are estimated to be $2 \mathrm{~m} / \mathrm{yr}$. Flow velocities in the active toe are in the range $1.3-2.5 \mathrm{~m} / \mathrm{yr}$.
The most recent phase of monitoring carried out at the active part of the Slumgullion landslide (a 3.5-year monitoring period, from July 1998 to March 2002) has shown that the landslide moved throughout the period but velocity varied on a seasonal basis (Coe et al., 2003). Seasonal variability in velocities is due to groundwater levels and corresponding pore pressures that increase when surface water from melting snow or rainfall infiltrates the landslide material. Therefore, seasonal variability in velocities appear to be primarily controlled by the availability of surface water (Coe et al., 2003).

As regards the present study, it has to be stressed the fact 
that the surface water quickly infiltrates the landslide through high permeability zones, which have been identified with patches of bouldery debris, and with fractures that are created at the ground surface by continuous movement (Coe et al., 2003; Parise et al., 2003). These surface features act as conduits for the infiltration of water, and this strongly points out to the importance of mapping their distribution and evolution at the surface of an active landslide. Furthermore, it has also been observed how the overall pattern in rate and distribution of movement at the surface of an active and slowmoving landslide can be locally influenced by the presence of major structural elements at the landslide surface (Fleming et al., 1988; Fleming and Johnson, 1989; Baum et al., 1996). Lack of data on the location and characters of these major structural elements, and their influence on variability of the landslide movement, may lead to incorrect interpretations of the spatial and/or seasonal variations in the landslide movement. This, in turn, could result in inaccurate evaluation of the landslide pattern, and cause wrong decisions when designing the more appropriate and stabilization works.

Even though with some limitations such as those outlined by Giardino (1996), that include topographic problems, reliability of the mapping due to state of activity of different features, and rheology of different materials, the multi-time surveying of surface features is therefore a low-cost approach that may produce the acquisition of a great amount of data about the evolution of a landslide, eventually resulting in information aimed at a better definition of the more appropriate intervention works.

This study, by describing some examples from the active part of the Slumgullion landslide, intended to stress the importance of large-scale geomorphological mapping, and especially of its repetitivity in time, for the study of active mass movements. In particular, the combination of: (1) detailed mapping of surface features; (2) information derived from indirect indicators of deformation; (3) measurement of displacement; (4) multi-time surveying; may result extremely useful for a better understanding of the landslide and its zonation in different elements characterized by different style of deformation.

Acknowledgements. I am grateful to many people that helped me during the work at Slumgullion: first and foremost, Robert Fleming and David Varnes were always open to discussion and provided me with precious advices and suggestions. Other people worked at different times with me at the landslide: Raffaela Guzzi, William Savage, Rex Baum, Marino Sorriso Valvo, Robert Schuster, Jeff Coe, Andrea Moscariello. To all of them, I express my most sincere gratitude.

This work is dedicated to the memory of Raffaela Guzzi, with whom I started in 1990 to map and study the surface features at the Slumgullion landslide.

\section{References}

Atwood, W. W. and Mather, K. F.: Physiography and Quaternary geology of the San Juan Mountains, Colorado. U.S. Geological Survey Professional Paper 166, 176 p., 1932.
Baum, R.L. and Fleming, R. W.: Use of longitudinal strain in identifying driving and resisting elements of landslides, Geol. Soc. Am. Bull., 103, 1121-1132, 1991.

Baum, R. L. and Fleming, R. W.: Kinematic studies of the Slumgullion landslide, Hinsdale County, Colorado, in: The Slumgullion earthflow: a large-scale natural laboratory, edited by Varnes, D. J. and Savage, W. Z., U.S. Geological Survey Bulletin 2130, 9-12, 1996.

Baum, R. L., Fleming, R. W., and Johnson, A. M.: Kinematics of the Aspen Grove landslide, Ephraim Canyon, central Utah, U.S. Geological Survey Bulletin 1842, F1-F34, 1993.

Burbank, W. S.: Lake City area, Hinsdale County, in Mineral Resources of Colorado, Colorado Mineral Resources Board, 439443, 1947.

Carter, M. and Bentley, S. P.: The geometry of slip surfaces beneath landslides: prediction from surface measurements, Can. Geotech. J., 22, 234-238, 1985.

Chleborad, A. F., Diehl, S. F., and Cannon, S. H.: Geotechnical properties of selected materials from the Slumgullion landslide, in: The Slumgullion earthflow: a large-scale natural laboratory, edited by Varnes, D. J. and Savage, W. Z., U.S. Geological Survey Bulletin 2130, 67-72, 1996.

Coe, J. A., Godt, J. W., Ellis, W. L., Savage, W. Z., Savage, J. E., Powers, P. S., Varnes, D. J., and Tachker, P.: Preliminary interpretation of seasonal movement of the Slumgullion landslide as determined from GPS observations, July 1998 - July 1999, U.S. Geological Survey Open-File Report 00-102, 25 p., 2000.

Coe, J. A., Ellis, W. L., Godt, J. W., Savage, W. Z., Savage, J. E., Michael, J. A., Kibler, K. D., Powers, P. S., Lidke, D. J., and Debray, S.: Seasonal movement of the Slumgullion landslide determined from Global Positioning System surveys and field instrumentation, July 1998 - March 2002, Engineering Geology, 68, 67-101, 2003.

Corominas, J.: Evidence of basal erosion and shearing as mechanism contributing to the development of lateral ridges in mudslides, flow-slides, and other flow-like gravitational movements, Engineering Geology, 39, 45-70, 1995.

Crandell, D. R. and Varnes, D. J.: Slumgullion earthflow and earthslide near Lake City, Colorado [abs.], Geological Society of America Bulletin, 71 (12), pt. 2, p. 1846, 1960.

Crandell, D. R. and Varnes, D. J.: Movement of the Slumgullion earthflow near Lake City, Colorado, in: Short Papers in the Geologic and Hydrologic Sciences, U.S. Geological Survey Professional Paper 424-B, B136-B139, 1961.

Cross, W.: The Slumgullion mud flow, Science, 30 (760), 126-127, 1909.

Cruden, D. M.: The geometry of slip surfaces beneath landslides: prediction from surface measurements. Discussion, Can. Geotech. J., 23, 94, 1986.

Cruden, D. M. and Varnes, D. J.: Landslide types and processes, in: Landslides. Investigation and mitigation, edited by Turner, A. K. and Schuster, R. L., Transp. Res. Board, Nat. Res. Council, Spec. Rep. 247, Washington, D.C., 36-75, 1996.

Deng, Q., Wu, D., Zhang, P., and Chen, S.: Structure and deformational character of strike-slip fault zones, Pure and Applied Geophysics, 124 (1-2), 203-223, 1986.

Diehl, S. F. and Schuster, R. L.: Preliminary geologic map and alteration mineralogy of the main scarp of the Slumgullion landslide, in: The Slumgullion earthflow: a large-scale natural laboratory, edited by Varnes, D. J. and Savage, W. Z., U.S. Geological Survey Bulletin 2130, 13-19, 1996.

Endlich, F. M.: Report of F.M. Endlich, in U.S. Geological and 
Geographical Survey (Hayden) of the Territories Annual Report 1874, 203 p., 1876.

Fleming, R. W. and Johnson, A. M.: Structures associated with strike-slip faults that bound landslide elements, Engineering Geology, 27, 39-114, 1989.

Fleming, R. W., Johnson, R. B., and Schuster, R. L.: The reactivation of the Manti landslide, in The Manti, Utah, landslide, U.S. Geol. Survey Professional Paper 1311, 1-22, 1988.

Fleming, R. W., Baum, R. L., and Giardino, M.: Map and description of the active part of the Slumgullion landslide, Hinsdale County, Colorado, U.S. Geological Survey Geologic Investigation Series I-2672, scale 1:1,000, 34 p., 1999.

Giardino, M.: Validità e limiti del rilevamento geomorfologico di deformazioni superficiali per l'analisi cinematica di fenomeni franosi: il caso della frana di Slumgullion, Colorado (USA), Proc. Int. Conf. "Prevention of Hydrogeological Hazards: The Role of Scientific Research", Alba (Italy), 1, 285-294, 1996.

Gomberg, J. S., Bodin, P. W., Savage, W. Z., and Jackson, M. E.: Landslide faults and tectonic faults, analogs? The Slumgullion earthflow, Colorado, Geology, 23 (1), 41-44, 1995.

Guzzi, R. and Parise, M.: Surface features and kinematics of the Slumgullion landslide near Lake City, Colorado, U.S. Geological Survey Open-File Report 92-252, 45 p., 1992.

Howe, E.: Landslides in the San Juan Mountains, Colorado, U.S. Geological Survey Professional Paper 67, 45 p., 1909.

Hutchinson, J. N.: Methods of locating slip surfaces in landslides, Bull. Ass. Eng. Geologists, 20 (3), 235-252, 1983.

IAEG Commission on Landslides: Suggested nomenclature for landslides, Bull. Int. Ass. Eng. Geology, 41, 13-16, 1990.

Johnson, A. M.: Physical processes in geology, Freeman, Cooper and Co., San Francisco, California, 577 p., 1970.

Keefer, D. K. and Johnson, A. M.: Earth flows: morphology, mobilization, and movement, U.S. Geological Survey Professional Paper 1264, 56 p., 1983.

Lipman, P. W.: Geologic map of the Lake City caldera area, western San Juan Mountains, south-western Colorado, U.S. Geological Survey Miscellaneous Investigations Series Map I-962, scale 1:48 000, 1976.

Madole, R. F.: Preliminary chronology of the Slumgullion landslide, Hinsdale County, Colorado, in: The Slumgullion earthflow: a large-scale natural laboratory, edited by Varnes, D. J. and Savage, W. Z., U.S. Geological Survey Bulletin 2130, 5-7, 1996.

Munsell, Munsell soil color charts, Munsell Color Company Inc., Baltimore, Maryland, USA, 1954.

Parise, M. and Guzzi, R.: Volume and shape of the active and inactive parts of the Slumgullion landslide, Hinsdale County, Colorado, U.S. Geological Survey Open-File Report 92-216, 29 p., 1992.

Parise, M. and Moscariello, A.: Geologic hazards and relative slope stability of the inactive part of the Slumgullion landslide, southwestern Colorado, U.S. Geological Survey Open-File Report 97706, 16 p., 1997.
Parise, M., Moscariello, A., and Fleming, R. W.: Evidence from flank ridges for long-term diminishing movements of the Slumgullion landslide, Hinsdale County, Colorado, U.S. Geological Survey Open-File Report 97-517, 14 p., 1997.

Parise, M., Coe, J. A., Savage, W. Z., and Varnes, D. J.: The Slumgullion landslide (southwestern Colorado, USA): investigation and monitoring, Proc. Int. Workshop "Flows 2003", Sorrento (Italy), 14-16 May, 2003.

Pollard, D. D., Segall, P., and Delaney, P. T.: Formation and interpretation of dilatant echelon cracks, Geol. Soc. Am. Bull., 93, 1291-1303, 1982.

Rickmers, W. R.: The Duab of Turkestan - a physiographic sketch and account of some travels, Cambridge Univ. Press, London, 197 p., 1913.

Schuster, R. L.: Landslide dams in the Western United States, Proc. IVth Int. Conf. and Field Workshop on Landslides, Tokyo, 411418, 1985.

Segall, P. and Pollard, D. D.: Mechanics of discontinuous faults, Journal of Geophysical Research, 85 (B8), 4337-4350, 1980.

Sharp, R. P.: Mudflow levees, Journal of Geomorphology, 5, 222 227, 1942.

Smith, R. L.: Photogrammetric determination of movement on the Slumgullion slide, Hinsdale County, Colorado, 1985-1990, U.S. Geological Survey Open-File Report 93-597, 1993.

Sylvester, A. G.: Strike-slip faults, Geol. Soc. Am. Bull., 100, 1666-1703, 1988.

Ter-Stepanian, G.: The use of observations of slope deformations for analysis of mechanism of landslides, Problems of Geomechanics, Armenian Academy of Science, 1, 32-51, 1967.

Varnes, D. J.: Landslide hazard zonation: a review of principles and practice, Unesco, Paris, 63 pp., 1984.

Varnes, D. J., Smith, W. K., Savage, W. Z., and Powers, P. S.: Deformation and control surveys, Slumgullion landslide, in: The Slumgullion earthflow: a large-scale natural laboratory, edited by Varnes, D. J. and Savage, W. Z., U.S. Geological Survey Bulletin 2130, 43-49, 1996.

Wieczorek, G. F.: Preparing a detailed landslide-inventory map for hazard evaluation and reduction, Bull. Ass. Eng. Geologists, 21 (3), 337-342, 1984.

Williams, G. P.: Stream-channel changes and pond formation at the 1974-76 Manti landslide, Utah, in: The Manti, Utah, landslide, U.S. Geol. Survey Professional Paper 1311, 43-69, 1988.

Williams, R. A. and Pratt, T. L.: Detection of the base of Slumgullion landslide, Colorado, by seismic reflection and refraction methods, in: The Slumgullion earthflow: a large-scale natural laboratory, edited by Varnes, D. J. and Savage, W. Z., U.S. Geological Survey Bulletin 2130, 77-83, 1996.

WP/WLI: (Working Party on World Landslide Inventory), A suggested method for describing the activity of a landslide, Bull. Int. Ass. Eng. Geology, 47, 53-57, 1993.

Zaruba, Q. and Mencl, V.: Landslides and their control, 2nd rev. Ed., Elsevier Scient. Publ. Company, Amsterdam, 323 p., 1982. 